\title{
A Study on the Relationship between the Attitude to the Globalization and Attitude to the Citizenship Rights
}

\author{
Habibolah Badri \\ Allameh Tabataba'i University, Tehran, Iran \\ Email: badrihabib93@gmail.com
}

Tahereh Oladghobad

M. S. in Educational Psychology, South Tehran Branch, Islamic Azad University, Tehran, Iran

Doi:10.5901/mjss.2015.v6n3s2p687

\begin{abstract}
One of the phenomena that has attracted attentions among scholars including sociologists, is the globalization matter and its effect on the other aspects of life. Given the importance of this topic, this paper is seeking to examine the relationship between globalization in various aspects and citizenship rights. The current research was conducted using descriptive and survey methods. The measurement research tool was researcher-made questionnaire with 5-point Likert scale that its face validity was confirmed based on experts' opinions and the literature of the study. Also, the reliability of research was confirmed using cronbach's alpha coefficient $95 \%$ which indicates the high reliability of the tool. The statistical population in this study consisted of all students at Tehran University. In this paper, based on determine the sample size formula, 103 people were selected by stratified random sampling proportional to the volume to participate in the research. To analyze the data, spss software was used. The results showed that there is significant relationship between globalization in cultural,social and economic dimensions and citizenship rights.
\end{abstract}

Keywords: globalization, rights, citizenship, cultural, social, economic

\section{Introduction}

Citizenship is the relation between the individual and the state that these two are bound together through mutual rights and obligations. The citizenship rights are linked to a particular political community that is usually defined in the constitutional framework of political units in various forms (Qavam, 2003, pp. 52-53). The universal declaration of human rights determines in this field that: the ideal of human's freedom and released from fear and poverty can be achieved if everyone's enjoyment of economic, social and cultural as well as civil and political rights is created. The economic, social and cultural rights can be found in components such as the right of freedom, choice of occupation and using authority requirements and satisfactory in addition to protection against unemployment and receiving equal pay and fair and satisfactory rewards, the right to housing, the right to form and join trade unions and syndicates.

The social dimension of citizenship indicates that citizens should be able to operate in different conditions and situations and have interaction. In the civil dimension of citizenship, the fundamental values of the society, decisions of the government limits in relation to the citizens, specify the rights and interactions of specific and interested groups. The political dimension of the citizenshiprefers to the relationship between the individuals in a social situation and also participating in an open political space and cultural dimension refers to the way of developing process of cultural diversity that is accompanied with issues such as the ability to accept other cultures, international migration, increased mobility and variability (Mohseni, 2010, 127-128).

One of the phenomena attracted a lot of attentions among scholars including sociologists, is the globalization matter and its effect on the other aspects of life. Globalization is a concept that deals with the compression of time and space and also awareness of this compression and its effect on economic, social, political and cultural dimensions of social life. In present era, because of the dependence of communities in above dimensions, any change and transition or any crisis in the corners of the earth can change or put in crisis other communities. Since in the last three decades, the citizenship rights has been following the discussion of globalization in political, social and civil aspects, it has been exposed to various and sometimes conflicting ups and downs and analysis. Issues such as identity, citizenship, citizenship rights, trade, investment, the process of the democratization of societies and economic development, civil and 
political libertiesare not possible to happen regardless of globalization. At this time, it is needed to be quite active in different political, social, cultural and economic arena. This activity and awareness of issues should be created and applied by both the government and the society. In this area, there are some sophisticated and professional actors who manage production and distribution of goods and services and even the creation of knowledge. Therefore, according to Castells, in the present era that economic has become purely informational and powerful countries have the monopoly of knowledge technology, and on the other side, within political systems of the societies (nation-state), it is felt that in sovereignty aspect towards globalization, they are being weakened, they try to fortify the basis of their governance to some extent, in different ways and contrary to the rights of the citizens and regardless of the wishes and demands of different groups and classes and in favor of global capitalist system, the sensitivity towards globalization is more important than ever before. Now it seems that the entrance of different countries in this international game requires a comprehensive understanding of themselves and relative familiarity with this phenomenon and its effect on citizen's rights. Since, along with this knowledge, we can embrace its positive aspects and refuse the negative aspects. Since the economic, social, political and cultural factors mutually influence each other, it is necessary to assess the rate of these changes on other aspects of social life in order to prevent unwanted and critical events or to minimize their consequences.

Given the importance of this topic, this article aims to investigate the effects and changes of globalization and study its aspects on dimensions of citizenship rights.

\section{Literature}

- Shiani and Dadvandi (2010),conducted a research entitled "analysis of the amount of citizenship rights knowledge among students". Based on the results, knowledge rate of citizenship rights wasn't equal among students. Among the various citizenship rights, most rate of knowledge was related to gender and the lowest rate was related to the civil dimension. Also, there was a significant relationship between the level of social knowledge and students' attitudes towards various subjects and the knowledge rate about citizenship rights.

- Lotfabadi (2006),conducted a study entitled "national and global citizenship education along with students' identity and value system consolidation". This paper emphasizes on three main issues related to each other including: first, explaining the basic concepts of globalization, universalism, global thinking and nationalism, national identity, value system. Citizenship and life skills and their relation to each other; second, presenting the author's research findings on the status of Iranian adolescents and youths, their attitude towards various aspects of social and civil life, value system, globalization, universalism and studying the important psychological characteristics that inhibit the growth of citizenship; third, explaining the meaning and the rights and the responsibilities of citizenship at local, national and global levels, the necessity and the quality of teaching students the philosophy and the correct way of thinking for thoughtful decision making in the field of citizenship. Grounded theory presented in this paper is: if Iran's education system wants to consolidate and promote national identity and value system and citizenship skills in children and teenagers, it must make them prepare to live in the globalization era in the present century. For this purpose, the attitude of the education system to the curriculum and classroom and school activities in general education must be changed. And in addition to curriculum training, strengthening the identity and the human, religious and national value system, they should put citizenship education and personal, social, economic, scientific and cultural life skills training in their educational programs. Teaching students about local, national and global citizenship is an important part of these programs. Studies presented in this paper show that considerable groups of Iranian teenagers and youths students have fundamental weaknesses in social and civil identity and are involved in antisocial attitudes and wrongdoing and have rebellious manner. In such a situation, it is necessary to train local, national and global rights and responsibilities in various aspects of citizenship in the curriculum and classroom and school activities and also to train behaving based on the right thinking, responsibility and thoughtful decision making. And also, in this study we will discuss how to train these programs.

- Ameli (2001) conducted a research entitled "interaction of globalization, citizenship and religion". In this article, three components of globalization, citizenship and religion were investigated. Since on the one handglobalization and religion are the same in being ultra temporal and ultra spatial and on the other hand, citizenship represents a kind of commitment to the civil principles and political, cultural and social affiliations,which a country have them inside its geographical and political, it is likely that there is a challenge between globalization, religion and citizenship. In this article, first, the concept of globalization is explained and then citizenship concepts are analyzed based on Marshal and Turner theory, and in the end, the views of 
these two thinkers are criticized.Due to the theoretical vacuity in citizenship model, a field study was conducted on citizenship and social belonging among British Muslims.

- Research done by Selvin (2002), Pangel and Pangel (2002), Starki (2003, quoted by Qoltash, 2009), on incidents, events and global and citizenship developments, ethical and social responsibility, information and communication qualifications, Chiodo (2005), in the area of understanding the concept of citizenship among high school students in America, Hess and Taley (2005), in national area and UNESCO (2010), in the field of cultural diversity and global identity, are some external research conducted in the field of citizenship studies.

\section{Hypotheses}

\subsection{The main hypothesis}

* What are the students' attitudes toward globalization and citizenship rights? And what are the effective factors?

\subsection{Sub-hypotheses}

* It seems that there is a relationship between social dimension of globalization and citizenship rights.

* It seems that there is a relationship between economic dimension of globalization and citizenship rights.

* It seems that there is a relationship between political dimension of globalization and citizenship rights.

* It seems that there is a relationship between cultural dimension of globalization and citizenship rights.

\section{Research Methodology}

The current research method was descriptive and the survey study method was used. The measurement research tool was researcher-made questionnaire with 5-point Likert scale that its face validity was confirmed based on experts' opinions and the literature of the study. The reliability of research was confirmed using cronbach's alpha coefficient $95 \%$ which indicates the high reliability of the tool. The statistical population in this study consisted of all students at Tehran University. In this paper, based on determine the sample size formula, 103 people were selected by stratified random sampling proportional to the volume to participate in the research. To analyze the data, spss software was used.

\section{Findings}

- It seems that there is a relationship between attitudes to the globalization and attitudes to the citizenship rights.

The results in table1 show that since the amount of test statistics (3.83) is greater than the amount of T-test in the table (1.645), so the null hypothesis is rejected. This means that there is a significant relationship between attitudes to the globalization in general and citizenship rights, thus the main hypothesis of the study is confirmed.

Table 1. T-student test results on the relationship between globalization and citizenship rights

\begin{tabular}{|c|c|c|c|c|c|}
\hline Mean & Standard deviation & Test statics & Degrees of freedom & T-test amount in the table & Test result \\
\hline 4.76 & 0.499 & 3.83 & 102 & 1.645 & Rejection of the null hypothesis \\
\hline
\end{tabular}

1 - It seems that there is a relationship between social dimension of globalization and attitudes toward citizenship rights.

Student T-test results in table2 show that since the test statistics value (2.18), is greater that the value of T-test in the table (1.645), as a result, the null hypothesis is rejected which means that there is a significant relationship between attitude to the globalization in social dimension and citizenship rights. Therefore, this hypothesis is confirmed.

Table 2. T-student test results on the relationship between globalization in social dimension and citizenship rights

\begin{tabular}{|c|c|c|c|c|c|}
\hline Mean & Standard deviation & Test statics & Degrees of freedom & T-test amount in the table & Test result \\
\hline 3.14 & 0.331 & 2.18 & 102 & 1.645 & Rejection of the null hypothesis \\
\hline
\end{tabular}


2 - It seems that there is a relationship between economic dimension of globalization and attitudes toward citizenship rights.

Student T-test results in table3 show that since the test statistics value (2.361) is greater that the value of T-test in the table (1.645), as a result, the null hypothesis is rejected and it means that there is a significant relationship between attitudes to the globalization in economic dimension and citizenship rights. Therefore, this hypothesis is confirmed.

Table 3. T-student test results on the relationship between globalization in economic dimension and citizenship rights

\begin{tabular}{|c|c|c|c|c|c|}
\hline Mean & Standard deviation & Test statics & Degrees of freedom & T-test amount in the table & Test result \\
\hline 3.44 & 0.029 & 2.361 & 102 & 1.645 & Rejection of the null hypothesis \\
\hline
\end{tabular}

3- It seems that there is a relationship between political dimension of globalization and attitudes toward citizenship rights.

The results in table4 show that since the amount of test statistics (-2.012) is less than the amount of T-test in the table (1.645), so the null hypothesis is confirmed, meaning that there is no relationship between attitudes to the globalization in political dimension and citizenship rights, thus this hypothesis of the study is rejected.

Table 4. T-student test results on the relationship between globalization in political dimension and citizenship rights

\begin{tabular}{|c|c|c|c|c|c|}
\hline Mean & Standard deviation & Test statics & Degrees of freedom & T-test amount in the table & Test result \\
\hline 2.25 & 0.5519 & -2.012 & 102 & 1.645 & verification of the null hypothesis \\
\hline
\end{tabular}

4- It seems that there is a relationship between cultural dimension of globalization and attitudes toward citizenship rights.

The results in table5 show that since the amount of test statistics (4.18) is more than the amount of T-test in the table (1.645), so the null hypothesis is rejected, meaning that there is a significant relationship between attitudes to the globalization in cultural dimension and citizenship rights, thus this hypothesis of the study is confirmed.

Table 5. T-student test results on the relationship between globalization in cultural dimension and citizenship rights

\begin{tabular}{|c|c|c|c|c|c|}
\hline Mean & Standard deviation & Test statics & Degrees of freedom & T-test amount in the table & Test result \\
\hline 3.84 & 0.0479 & 4.18 & 102 & 1.645 & Rejection of the null hypothesis \\
\hline
\end{tabular}

\section{Conclusion}

A summary of findings is presented in here:

- In the main hypothesis of the study's case, since the amount of test statistics (3.83) is greater than the amount of T-test in the table (1.645), so we can say that there is a significant relationship between attitudes to the globalization in general and citizenship rights.

- On the first hypothesis of the study, since the test statistics value (2.18) is more that the value of T-test in the table (1.645), so we can say that there is a significant relationship between attitude to the globalization in social dimension and citizenship rights.

- For the second hypothesis, since the test statistics value (2.361) is greater that the value of T-test in the table (1.645), as a result we can say that there is a significant relationship between attitudes to the globalization in economic dimension and citizenship rights.

- $\quad$ About the third hypothesis, since the amount of test statistics (-2.012) is less than the amount of T-test in the table (1.645), thus we could conclude that there is no relationship between attitudes to the globalization in political dimension and citizenship rights.

- And about the forth hypothesis, since the amount of test statistics (4.18) is more than the amount of T-test in the table (1.645), therefore, we can say that there is a significant relationship between attitudes to the globalization in cultural dimension and citizenship rights.

\section{Suggestions}

- Understanding the current situation of the world is one of the basic necessities which if it is actualized, it will be possible to achieve a proper status in global relations. 
- Given the importance of information and knowledge in social and international relations and sustainable development of communities, honoring involved processes and factors causes to ensure that everyone could utilize this vital phenomenon.

- Quick changes and developments in the field of science and technology have made clear the necessity of updating and synchronizing with the progresses more than before.

- Cultural complex studies the community systematically because in this way, we can achieve training, preparation and protection more than deterrence and get the immunization more than passive escape and also we could attain active and creative encounter in facing the elements of West cultural system.

- Providing and developing comprehensive strategies on the process of globalization considering different features and various cultural, economic, political, social and technological dimensions of this phenomenon.

- With respect to the combinatory status of this phenomenon which has positive results and negative effects, there are widespread vulnerabilities in this process but this doesn't mean rejecting the logic of globalization. But it means to find solutions for global problems with global logic and vision. So the most efficient way is to use developing technologies of the world with the lowest cost.

- It is essential to identify experiences and perspectives of other people for globalization to create a comprehensive strategy for countries.

\section{References}

Shiani, M., and Dadvandi, T. (2010). Analysis of knowledge level on citizenship rights among students. Journal of Welfare and Social Development Planning. No. 5, Pp. 36-59.

Ameli, S. (2001). Interaction of globalization, citizenship and religion.Social Science Journal. Vol. 9, No. 18, Pp. 167-200.

Mohseni, R. (2010). Dimensions and analysis of citizenship rights; guidelines for the education and training citizenship rights.Political Studies. Vol. 3, No. 10, Pp. 117-144.

Qavam, A. (2003). Globalization and the third world; globalization process and the position of developing countries in international system. Tehran: Ministry of Foreign Affairs.

Qoltash, A. (2009). Reviewing the citizenship education approaches in the curriculum of primary schools in Iran and providing curriculum plan of citizen training. PhD dissertation on curriculum. Islamic Azad University, Khourasgan branch.

Lotfabadi, H. (2006). National and global citizenship training along with strengthening students' identity and value system.Journal of Educational Innovations. No. 17, P. 11.

Selwyn N. 2002.Literature review in citizenship, technology and learning. report 3: NESTA futurelabscence. cardiff: NESTA future, available from www.futurelab.org.uk/resources/.../Citizenship_Review_update.pdf.

Pangle L S, Pangle I L. 2002. What the American founder have to teach us about schooling for democratic citizenship. University press of Kansas.

Chiodo J.J. Lisa, A M. 2005. What do students have to say about citizenship?An analysis of the concept of citizenship among secondary education student. Journal of social studies research.

Heath A F, Tilley J R.2005.British national identity and attitudes towards immigration. university of Oxford ,International journal on multicultural societies (IJMS), 7/ 2:119-132.

Unesco.2010. Citizenship education for the 21st century.Available from http://www.unesco.org/education/tlsf/TLSF/theme_b/mod07 Imod07task0 3/appendixhtm [Accessed 2010-01-27 4:42 pm]. 